\title{
STRUCTURAL CHANGE IN THE BRAZILIAN ECONOMY IN THE 2000s(*)
}

\begin{abstract}
Alexandre Messa $a^{a}$
ABSTRACT: This paper investigates the sources of structural change in the Brazilian economy in the 2000s. On that purpose, it uses the input-output structural decomposition analysis and introduces a method to correct the influence of prices on the time behavior of the technical coefficients, making them actually represent changes in the production structure. Results show that most of the growth differential between services and industry in that period was induced by the production structure: more precisely, by a lower intermediate consumption of domestic industrial inputs by the production chain of all economic sectors, concomitant with a higher intermediate consumption of services.
\end{abstract}

KEYWORDS: Structural change; input-output analysis.

JEL CLASSIFICATION: C67; O10; O14.

* Artigo recebido em 24/10/2012 e aprovado em 16/01/2014.

a Doutor em Teoria Econômica pela Faculdade de Economia e Administração da Universidade de São Paulo (FEA/USP) e técnico de planejamento e pesquisa do Instituto de Pesquisa Econômica Aplicada (IPEA).Contato: alexandre.silva@ipea.gov.br. 


\section{MUDANÇAS ESTRUTURAIS NA ECONOMIA BRASILEIRA AO LONGO DA DÉCADA DE 2000}

RESUMO: Este artigo investiga as fontes das mudanças estruturais da economia brasileira ao longo da década de 2000. Para tal, utiliza-se a análise de decomposição estrutural de insumo-produto e introduz-se um método que corrige a influência dos preços sobre o comportamento dos coeficientes técnicos ao longo do tempo, fazendo com que estes reflitam de fato a evolução da estrutura produtiva. Os resultados obtidos mostram que a maior parte do diferencial de crescimento ente os serviços e a indústria durante aquele período foi induzida pela estrutura produtiva: mais precisamente, por um menor consumo intermediário de insumos industriais domésticos pela cadeia produtiva de todos os setores da economia, concomitante a um maior consumo intermediário de serviços.

PALAVRAS-CHAVE: Mudança estrutural; análise de insumo-produto. 


\section{INTRODUCTION}

In the 2000s, Brazilian economy established a model based on the expansion of consumption and on low savings rates, supported by the export of commodities and the absorption of foreign savings. Despite the fact that the manufacturing's declining share of the Brazilian Gross Domestic Product (GDP) was largely a 1980s phenomenon - see Nassif (2008) -, the behavior of the real exchange rate induced by this model sparked a heated debate about structural change in the Brazilian economy ${ }^{3}$.

The unequal growth across sectors in modern economies was first documented by Kuznets (1966). Since then, the economic growth literature has dealt with this issue from two different perspectives. From the preferences one, consumers would tend to change their consumption habits as their incomes increase: first, their preference would be toward agricultural goods, in order to meet basic survival needs; after satisfying these needs, consumers would demand industrial goods; finally, at a given income level, consumers would begin to demand an array of non-essential services ${ }^{4}$.

Alternatively, Baumol (1967) introduces the idea that unbalanced growth across sectors may be a consequence of an unequal technological progress: through time, those sectors whose productivity grew more slowly (usually associated to services) would tend to use larger shares of the production factors in order to satisfy their demands; therefore, their costs and prices would tend to increase compared to more dynamic sectors (commonly associated to manufacturing); consequently, those sectors shares of employment and value of production were expected to increase over time ${ }^{5}$.

In fact, these standpoints complement each other and both forces should be present all along. However, the idea that structural changes in the economy could result from factors either on the demand side or on the supply one hinders the proper interpretation of the phenomena that underlie economic changes.

Using that as a starting point, this paper investigates the sectoral dynamics in the Brazilian economy in the 2000s, in order to make a distinction between the effects produced by the demand side and by the supply one on recent structural changes. The study is limited to this period due especially to two factors. First, such restraint allows focusing the analysis on changes resulting from the current Brazilian economic model, based on the expansion of consumption and on a low savings rate. Secondly, in more practical terms, it enables an analys is limited to a period in which the verification of

\footnotetext{
3 See, for instance, Bonelli and Pessôa (2010) and Oreiro and Feijó (2010), in addition to Nassif (2008).

4 This is an age-old idea in the economic theory, which alludes to Engel's law. Kongsamut, Rebelo and Xie (2001) introduce these kinds of preferences in a dynamic sectoral model.

5 Ngai and Pissarides (2007) develop this idea in a neoclassical model of economic growth.
} 
the System of National Accounts by the Brazilian Institute of Geography and Statistics (IBGE) follows a common methodology.

To achieve these goals, this paper relies on an input-output analysis. This method is appropriate in this context because, on the one hand, different industries are actually interdependent. The service sector, for instance, demands inputs from the manufacturing industry and vice versa. Therefore, an increase in the demand for services also produces a boost in the demand for manufacturing inputs, and a lower demand for industrial goods may lead to a smaller relative importance of certain services. Thus, to properly assess the effect of final demand on different sectors, it is necessary to analyze the production structure of the consumer goods and services. On the other hand, regardless of the behavior of final demand, changes in production techniques can also condition the sectoral dynamics. Suitably, the input-output analysis allows for the proper decomposition of structural changes resulting from either the behavior of final demand or the technological progress.

Hence, this paper is related to the literature on input-output structural decomposition analysis, which investigates the sources of changes in the economy using comparative statics exercises through input-output matrices. This line of research has several applications and has given rise to a large body of studies. In fact, an assessment of this literature goes beyond the scope of this paper. For this, the review made by Rose and Casler (1996) is still a benchmark. Among the applications, it is worth citing Feldman, McClain and Palmer (1987) for the analysis of the U.S. economy, Skolka (1989) for the Austrian one, and, more recently, Ma and Stern (2008) and Lim, Yoo and Kwak (2009) for studies, respectively, on energy consumption in China and on $\mathrm{CO}_{2}$ emission by the Korean industry.

However, although the coefficients of input-output matrices are often interpreted in terms of physical quantities, these matrices are actually developed, by the respective statistical institutes of each country, using monetary values. Consequently, the behavior of these coefficients over time does not reflect exactly the production structures of each sector, but actually their cost structures.

This paper then introduces a method that intends to correct the influence of prices on the technical coefficients. In this way, it becomes possible to interpret the effects of these coefficients on output growth strictly in terms of physical quantities, as resulting from changes in the production structure of the respective sectors.

Between 2000 and $2009^{6}$, the respective outputs of the agricultural, industrial and service sectors grew, at constant prices, at rates of $46.0 \%, 19.3 \%$ and $35.4 \%$. With re-

\footnotetext{
${ }^{6}$ At the time this paper was written, 2009 was the last year of the System of National Accounts series published by IBGE.
} 
gard to the first one, this paper shows, among other results, that final demand was the major determining factor for its growth. Among the components of this demand, the most relevant for agriculture were personal consumption expenditures and exports, which led, each one alone, to a growth of $18.6 \%$ and $12.7 \%$, respectively, of this sector.

In addition, this paper points out that $59 \%$ of the growth differential (of $16.1 \%$ ) between services and industry was due to changes in the input-output relations of these sectors. More precisely, it can be noted, in a way common to the three sectors, both a smaller intermediate consumption of domestic industrial inputs - which led alone to a $5.6 \%$ decrease in the industrial output -, and a higher consumption of inputs from services - resulting by itself in a $3.8 \%$ increase in the output of this sector.

Then, the remaining $41 \%$ of the growth differential between services and industry was due to demand-side factors. As to the components of this demand, three of them stand out for different reasons: gross fixed capital formation, government consumption expenditures and personal consumption expenditures. The first one contributed negatively to that differential (by $-40.2 \%$ ) - i.e., it favored the growth of industry more than the services one.

In their turn, the other two components accounted, respectively, for $38.5 \%$ and $32.9 \%$ of that differential. However, these components differ from each other due to the fact that, while government consumption exerted an important impact only on services (especially on the own services of public administration, health and education), personal consumption shows an influence on the whole economy (even though, throughout the analyzed period, this influence was more significant on the service sector).

To carry out this analysis, the present paper is organized into three sections in addition to this introduction. Using the input-output model, section 2 derives the structural decomposition from which the results are obtained. These, in turn, will be reported and analyzed in section 3 . Finally, section 4 concludes.

\section{STRUCTURAL DECOMPOSITION}

In view of the input-output analysis of an economy disaggregated into $n$ sectors, define: $q$, an $n \times 1$ vector of sectoral outputs; $A$, an $n \times n$ matrix of technical coefficients; and $f$, an $n \times 1$ vector of final demand for the output of each sector. Then, the vector $q$ of sectoral outputs can be expressed by equation $q=A q+f$. After algebraic manipulations, one obtains the input-output model relating the respective sectoral outputs to final demand:

$$
q=C f
$$


where $C=(I-A)^{-1}$, and $I$ is an $n \times n$ identity matrix. By means of equation (1), one obtains vector $q$ of sectoral outputs from vector $f$ of final demand and from matrix $C$. In this matrix, the entry $\mathrm{C}^{\mathrm{ij}}$ (referring to row $i$ and column $j$ ) expresses the fraction of monetary unit of the output of sector $i$ necessary to produce one monetary unit of the output of sector $j$.

Consider then two time instants: an initial time zero, and a final time $t>0$. Using subscripts to tell them apart, one has the respective outputs at each time: $q_{0}=C_{0} f_{0}$ and $q_{t}=C_{t} f_{t}$. Define $p_{t}^{i}, i=1, \ldots, n$, as the ratio between the prices of the output of sector $i$ at $t$ and at zero, and let $\pi_{t}$ be the $n \times 1$ vector of sectoral deflators, such that $\pi_{t}=\left[1 / p_{t}^{1}, \ldots, 1 / p_{t}^{n}\right]$. Applying the Hadamard ${ }^{7}$ product (denoted below by ${ }^{\circ}$ ) on both sides of equation (1),

$$
\pi_{t} \circ q_{t}=\pi_{t} \circ\left(C_{t} f_{t}\right)
$$

The vector $\pi_{t} \circ q_{t}, n \times 1$ denotes the deflated sectoral output at time $t$, adopting zero as base time. Subtracting $q_{0}$ on both sides of (2) and recalling that $q_{0}=C_{0} f_{0}$,

$$
\pi_{t} \circ q_{t}-q_{0}=\pi_{t} \circ\left(C_{t} f_{t}\right)-C_{0} f_{0}
$$

The left-hand side of the above equation represents the growth of sectoral output, in absolute terms, through the period between zero and $t$. Adding and subtracting the terms $C_{t}\left(f_{t} \circ \pi_{t}\right)$ and $C_{0}\left(f_{t} \circ \pi_{t}\right)$ on the right-hand side of equation (3),

$$
\begin{aligned}
\pi_{t} \circ q_{t}- & q_{0}=\pi_{t} \circ\left(C_{t} f_{t}\right)-C_{t}\left(f_{t} \circ \pi_{t}\right) \\
+ & \left(C_{t}-C_{0}\right)\left(f_{t} \circ \pi_{t}\right) \\
& +C_{0}\left(f_{t} \circ \pi_{t}-f_{0}\right)
\end{aligned}
$$

The right-hand side of the above equation decomposes sectoral output growth into effects of the input-output relations (the sum of the first two lines) and effects of the final demand (third line). To properly understand this decomposition, let $\left[\pi_{t}^{\circ} q_{t}-q_{0}\right]_{i}$ be the output growth of sector $i$, $C^{\mathrm{ij}}$ the entry of matrix $C$ for row $i$ and column $j$, and $f^{\mathrm{i}}$ the entry for row $i$ of vector $f$. Then, taking $i=1$ as an example, by equation (4),

Let $A$ and $B$ be $m \times n$ matrices. The Hadamard product $A \circ B$ yields a matrix of same dimension $m \times n$, such that $(A \circ B)^{i j}=(A)^{i j}(B)^{i j}$ where $(\bullet)^{i j}$ denotes the entry for row and column of the said matrix. 


$$
\begin{aligned}
{\left[\pi_{t} \circ q_{t}\right.} & \left.-q_{0}\right]_{1}=C_{t}^{11} f_{t}^{1}\left(\frac{1}{p_{t}^{1}}-\frac{1}{p_{t}^{1}}\right)+\ldots+C_{t}^{1 n} f_{t}^{n}\left(\frac{1}{p_{t}^{1}}-\frac{1}{p_{t}^{n}}\right) \\
+ & {\left[\left(C_{t}^{11}-C_{0}^{11}\right) \frac{f_{t}^{1}}{p_{t}^{1}}+\ldots+\left(C_{t}^{1 n}-C_{0}^{1 n}\right) \frac{f_{t}^{n}}{p_{t}^{n}}\right] } \\
+ & C_{0}^{11}\left(\frac{f_{t}^{1}}{p_{t}^{1}}-f_{0}^{1}\right)+\ldots+C_{0}^{1 n}\left(\frac{f_{t}^{n}}{p_{t}^{n}}-f_{0}^{n}\right)
\end{aligned}
$$

The third line of the above equationgives the effect of the final demand on sectoral output: by keeping constant the production structure (given by $C_{0}$ ), it expresses the impact on output resulting from changes in final demand (given by $\left(f_{t} \circ \pi_{t}-f_{0}\right)$ ). Thus, for example, in (5), $C_{0}^{1 j}$ represents the value of the input supplied by sector $i=1$ necessary to produce one monetary unit of the sector $j$ good, whereas $\left(f_{t}^{j} / p_{t}^{j}-f_{0}^{j}\right)$ represents the growth of the final demand for this good. Note also that the effects of the final demand on a given sector can be either direct, by means of the final demand for its own output, or indirect, through the supply of inputs to the production chain of other sector whose outputs meet final demand.

The second line represents the output growth due to changes in the production structure: $\left(C_{t}^{1 j}-C_{0}^{1 j}\right)$ stands for the variation in the value of the input supplied by sector $i=1$ necessary to produce one monetary unit of the output of sector $j$. Meanwhile, the first line corrects the influence of prices on these variations: considering fixed both the value of the input supplied by sector $i=1$ necessary to produce one monetary unit of output of sector $j$ (given by $C_{t}^{1 j}$ ), and the final demand for this output (given by $f_{t}^{j}$ ), the changes in relative sector prices make it necessary an amount $\left(1 / p_{t}^{1}-1 / p_{t}^{j}\right)$ times larger of input from sector $i=1$. Thus, whereas the second line gives the effect of input-output relations on sectoral output growth in terms of values, the sum of the first two lines allows the interpretation of such an effect in terms of quantities.

\section{RESULTS}

In the following analysis, the years 2000 and 2009 represent, respectively, the time zero and $t$ of equations ( 1 ) to (5) from the previous section. Matrices $q_{2000}, C_{2000}$ and $f_{2000}$ were obtained from the Input-Output Matrices series published by IBGE. In turn, vec- 
tor $q_{2009}$ was obtained from the System of National Accounts data for 2009, also published by IBGE. Matrices $A_{2009}$ and $f_{2009}$ were also obtained from the System of National Accounts for 2009, but using the method developed in Maciente (2013) ${ }^{8}$. From these matrices, one obtains $C_{2009}=\left(I-A_{2009}\right)^{-1}$. Finally, to obtain vector $\pi_{2009}$, it was used the implicit GDP deflator, also obtained from the SNA data.

The following calculations were made using the data concerning the disaggregation of product and activities into the level 12 of the classification used by the SNA/ IBGE. The results for the agricultural, industrial and service sectors were obtained from later aggregation of the calculations made at a more disaggregated level.

Table 1 shows the percentage output growth between 2000 and 2009, at constant prices, for the 12 activities and their respective aggregations. Note, for instance, that the mineral extraction industry and information services stand out in terms of relative growth (75.0\% and $64.2 \%$, respectively).

Table 1 - Output growth between 2000 and 2009

\begin{tabular}{lccc}
\hline \multicolumn{1}{c}{ Sector } & Growth (\%) & \multicolumn{1}{c}{ Activity } & Growth (\%) \\
\hline Agriculture & 46.0 & Agriculture & 46.0 \\
\hline Industry & 19.3 & Mineral extraction industry & 75.0 \\
& & Manufacturing industry & 15.7 \\
& & 32.2 \\
& & Production and distribution of electricity, gas and water & 14.9 \\
\hline Services & Construction & 32.2 \\
& & Trade & 34.5 \\
& & Transport, storage and mail services & 64.2 \\
& & Information services & 37.2 \\
& & Financial intermediation, insurance and pension funds & 42.9 \\
& & Real estate activities andrent & 32.2 \\
& & Other services & 28.1 \\
\hline
\end{tabular}

Source: Data compiled by the author from Input-Output Matrices for 2000 and from the System of National Accounts for 2009, both published by IBGE.

Table 2 summarizes the output growth decomposition as to the effects of input-output relations and of final demand, according to equation (4), but in percentage terms. For example, according to Table 2, $20.5 \%$ and $79.5 \%$ of the growth of the agri-

8 The extraction of these matrices from the System of National Accounts involves the transformation of the matrices of intermediate consumption and final demand, both expressed at current prices, into the same matrices at basic prices. To this end, the present paper resorts to Maciente (2013). For a concurrent method, see Guilhoto and Sesso Filho (2010). 
cultural sector was due, respectively, to the effects of input-output relations and of final demand ${ }^{9}$.

Table 2 - Effects on output growth between 2000 and 2009

\begin{tabular}{lcc}
\hline \multirow{2}{*}{ Sector } & \multicolumn{2}{c}{ Effects } \\
\cline { 2 - 3 } & Input-output ratios (\%) & Final demand (\%) \\
\hline Agriculture & 20.5 & 79.5 \\
Industry & -28.8 & 128.8 \\
Services & 10.9 & 89.1 \\
\hline Activity & Input-output ratios (\%) & Final demand (\%) \\
\hline Agriculture & 20.5 & 79.5 \\
Mineral extraction industry & 19.2 & 80.8 \\
Manufacturing industry & -53.7 & 153.7 \\
Generation and production of electricity, gas and water & 17.5 & 82.5 \\
Construction & -14.3 & 114.3 \\
\hline Trade & 11.4 & 88.6 \\
Transport, storage and mail services & 21.0 & 79.0 \\
Information services & 32.4 & 67.6 \\
Financial intermediation, insurance andpension funds & 13.0 & 87.0 \\
Real estate activities and rent & 16.1 & 83.9 \\
Other services & 1.7 & 98.3 \\
Public administration, health and education & -2.7 & 102.7 \\
\hline
\end{tabular}

Source: Data compiled by the author based on the Input-Output Matrices for 2000 and the System of National Accounts data for 2009, both published by IBGE.

Three important conclusions can be drawn from Table 2. First, it can be noted that final demand was the major factor of growth for all activities in the 2000s.

Second, input-output relations contributed to the contraction of two industrial activities: manufacturing and construction. In other words, a lower intermediate consumption of inputs supplied by these two activities accounted for a decrease in their output equivalent to $8.4 \%{ }^{10}$ and $2.1 \%{ }^{11}$, respectively. At a more aggregate level, this lower intermediate consumption led to a decrease of $5.6 \%{ }^{12}$ in industrial output.

\footnotetext{
9 Therefore, once that, according to Table 1,agriculture had a $46 \%$ growth, the effects of input-output relations and of final demand accounted for the respective growths of $9.4 \%(46 \% \times 20.5 \%)$ and $36.5 \%(46 \%$ $\times 79.5 \%)$ of this sector.

$10 \quad 15.7 \%$ (Table 1$) \times(-53.7 \%)$ (Table 2$)=-8.4 \%$.

11 14.9\% (Table 1) $\times(-14.3 \%)$ (Table 2$)=-2.1 \%$.

$1219.3 \%$ (Table 1$) \times(-28.8 \%)$ (Table 2$)=-5.6 \%$.
} 
Third, the effects of input-output relations and of final demand yielded a growth of $-5.6 \%{ }^{13}$ and $24.9 \%{ }^{14}$, respectively, for the industry, and $3.8 \%{ }^{15}$ and $31.6 \%{ }^{16}$ for services. Therefore, the growth differential between services and industry induced by the effects of input-output relations corresponds to $9.4 \%{ }^{17}$ (accounting for $59 \%$ of the $16.1 \%$ differential), while that induced by the effects of the final demand amounts to $6.7 \%^{18}$ (or $41 \%$ of the overall differential).

Table 3 shows the sectors responsible for the effects of input-output relations on each sector ${ }^{19}$. For example, recall that, according to Table 2, the increase in intermediate consumption of agricultural inputs accounted for a $20.5 \%$ growth of this sector. Thus, according to Table 3, 99.7\% of this growth originated from an increase in intermediate consumption was induced by industry, while percentages equivalent to $1.9 \%$ and $-1.6 \%$ were induced, respectively, by the service and agricultural sectors.

Table 3 - Decomposition of the effects of input-output relations (\%)

\begin{tabular}{lccc}
\hline \multirow{2}{*}{ Influenced sector } & \multicolumn{3}{c}{ Inducing sector } \\
\cline { 2 - 4 } & Agriculture & Industry & Services \\
\hline Agriculture & -1.6 & 99.7 & 1.9 \\
Industry & -2.1 & -58.9 & -39.0 \\
Services & 0.7 & 59.0 & 40.4 \\
\hline
\end{tabular}

Source: Data compiled by the author based on the Input-Output Matrices for 2000 and the System of National Accounts data for 2009, both published by IBGE.

Two conclusions can be established from Table 3. First, the smaller demand for industrial inputs, which was responsible for a reduction in industrial output, is a common phenomenon to the production chains of the three sectors. Second, a larger demand for inputs necessary to produce industrial goods was relevant to the growth of both the agricultural and the service sectors (but especially for the former one).

\footnotetext{
$13 \quad 19.3 \%$ (Table 1$) \times(-28.8 \%)$ (Table 2$)=-5.6 \%$.

$14 \quad 19.3 \%$ (Table 1$) \times 128.8 \%$ (Table 2$)=24.9 \%$.

$1535.4 \%$ (Table 1 ) $\times 10.9 \%$ (Table 2$)=3.8 \%$.

$16 \quad 35.4 \%$ (Table 1$) \times 89.1 \%$ (Table 2$)=31.6 \%$.

$173.8 \%-(-5.6 \%)=9.4 \%$.

$18 \quad 31.6 \%-24.9 \%=6.7 \%$.

19 Table 3 has to be interpreted with caution. It does not refer to the intermediate consumption, by the sectors in the columns, of inputs supplied by the sectors in the rows, but rather to the intermediate consumption of inputs of sectors in the rows throughout the production chain of the sectors shown in the columns.
} 
Table 4 exhibits the same results of Table 3, but disaggregated into the 12 activities. Note that the positive effects for agriculture and services from the larger intermediate consumption of inputs supplied by these sectors for the production of industrial goods were caused mainly by the production chain of the manufacturing industry ${ }^{20}$.

Table 4 - Disaggregated decomposition of the effects of input-output relations (\%)

\begin{tabular}{|c|c|c|c|c|c|c|c|}
\hline \multirow{2}{*}{$\mathbf{N}$} & \multirow{2}{*}{ Influenced activity } & \multicolumn{6}{|c|}{ Inducing activity $(\mathrm{N})$} \\
\hline & & 1 & 2 & 3 & 4 & 5 & 6 \\
\hline 1 & Agriculture & -1.6 & 0.2 & 91.2 & 0.3 & 8.1 & 4.1 \\
\hline 2 & Mineral extraction industry & 0.0 & 6.1 & 52.2 & 18.3 & 13.0 & 4.4 \\
\hline 3 & Manufacturing industry & -1.7 & -1.7 & -52.4 & -0.7 & -3.5 & 1.6 \\
\hline 4 & Generation and distribution of electricity, gas and water & -1.5 & -1.7 & 65.9 & -24.9 & -13.0 & 14.5 \\
\hline 5 & Construction & -0.6 & 5.2 & -9.3 & 0.2 & -82.3 & -0.7 \\
\hline 6 & Trade & 6.0 & 0.9 & 110.8 & 0.1 & 3.1 & 10.5 \\
\hline 7 & Transport, storage and mail services & -1.6 & 4.8 & 56.7 & 6.0 & 1.5 & 31.5 \\
\hline 8 & Information services & 0.4 & 1.8 & 12.6 & 0.6 & 1.6 & 6.3 \\
\hline 9 & Financial intermediation, insurance and pension funds & -0.3 & -0.5 & 109.3 & -3.1 & 16.3 & 22.7 \\
\hline 10 & Real estate activities and rent & 1.4 & 9.9 & 38.7 & 0.7 & -4.7 & 9.2 \\
\hline 11 & Other services & -4.5 & 39.6 & 54.7 & -1.9 & -35.9 & 105.4 \\
\hline 12 & Public administration, health and education & -3.3 & -1.6 & -35.0 & -2.0 & -9.2 & -4.0 \\
\hline \multirow{2}{*}{$\mathbf{N}$} & \multirow{2}{*}{ Influenced activity } & \multicolumn{6}{|c|}{ Inducing activity $(\mathrm{N})$} \\
\hline & & 7 & 8 & 9 & 10 & 11 & 12 \\
\hline 1 & Agriculture & 5.4 & -0.3 & -4.3 & 0.2 & -5.3 & 2.2 \\
\hline 2 & Mineral extraction industry & 4.0 & 0.1 & -3.1 & 0.2 & -1.7 & 6.3 \\
\hline 3 & Manufacturing industry & 3.1 & -1.8 & -8.8 & -0.7 & -24.1 & -9.2 \\
\hline 4 & Generation and distributionof electricity, gas and water & 20.6 & 6.1 & -11.2 & 2.4 & -1.7 & 44.5 \\
\hline 5 & Construction & -1.6 & 1.5 & -21.9 & -28.6 & -33.2 & 71.4 \\
\hline 6 & Trade & -4.5 & -3.2 & -12.3 & -0.4 & -17.8 & 6.9 \\
\hline 7 & Transport, storage and mail services & 29.5 & -3.0 & -6.8 & 1.0 & -20.9 & 1.5 \\
\hline 8 & Information services & 2.4 & 13.4 & 4.4 & 1.9 & 7.2 & 47.3 \\
\hline 9 & Financial intermediation, insurance and pension funds & 14.5 & 6.3 & -62.5 & 9.5 & -1.1 & -11.1 \\
\hline 10 & Real estate activities and rent & -2.0 & -3.4 & -4.4 & 4.1 & -6.0 & 56.4 \\
\hline 11 & Other services & -38.9 & -74.3 & -195.9 & 78.4 & -253.9 & 427.1 \\
\hline 12 & Public administration, health and education & -3.9 & -3.7 & -8.6 & 0.3 & -22.1 & -7.0 \\
\hline
\end{tabular}

Source: Data compiled by the author based on the Input-Output Matrices for 2000 and the System of National Accounts data for 2009, both published by IBGE.

Table 5 allows the identification of the share of growth of each sector induced by the final demand from each of the other sectors. In this way, it can be seen that, on the one hand, the increase in the final demand for industrial goods had a significant impact on

\footnotetext{
${ }^{20}$ To see that, observe the column referring to $N=3$.
} 
the growth of agriculture (accountable for a $10.8 \%^{21}$ increase in the output of this sector), and, on the other hand, the increase in the final demand for services was also relevant for the growth of industry (leading to an increase of $5.1 \%{ }^{22}$ in the industrial output).

Table 5 - Decomposition of the effects of final demand (\%)

\begin{tabular}{lccc}
\hline & Influenced sector & \multicolumn{3}{c}{ Inducing sector } \\
\cline { 2 - 4 } & Agriculture & Industry & Services \\
\hline Agriculture & 60.3 & 29.4 & 10.3 \\
Industry & 3.3 & 76.2 & 20.5 \\
Services & 1.0 & 9.9 & 89.1 \\
\hline
\end{tabular}

Source: Data compiled by the author based on the Input-Output Matrices for 2000 and the System of National Accounts data for 2009, both published by IBGE.

\subsection{FINAL DEMAND COMPONENTS}

The final demand item of the System of National Accounts consists of the sum of six components: exports, government consumption expenditures, consumption of nonprofit institutions serving households (NPISH), personal consumption expenditures, gross fixed capital formation and changes in inventories. Table 6 shows the percentage growth of each one of these components throughout the period between 2000 and 2009.

Table 6 - Growth of the final demand components between 2000 and 2009

\begin{tabular}{lc}
\hline \multicolumn{1}{c}{ Demand component } & Growth (\%) \\
\hline Exports & 39.7 \\
Government consumption expenditure & 29.6 \\
NPISH consumption & 26.1 \\
Personal consumption expenditure & 29.8 \\
Gross fixed capital formation & 37.8 \\
Changes in inventories & -120.6 \\
Total & 29.7 \\
\hline
\end{tabular}

Source: Data compiled by the author based on the Input-Output Matrices for 2000 and the System of National Accounts data for 2009, both published by IBGE.

Table 7 exhibits the percentage values of the effects of final demand on each sector for which the respective components were accountable. For instance, note that, according to Table 2, the effects of the final demand accounted for $79.5 \%$ of the growth of

\footnotetext{
${ }^{21} 46 \%$ (Table 1) $\times 79.5 \%$ (Table 2) $\times 29.4 \%$ (Table 5) $=10.8 \%$.

$2219.3 \%$ (Table 1$) \times 128.8 \%($ Table 2$) \times 20.5 \%$ (Table 5$)=5.1 \%$.
} 
agriculture. In its turn, Table 7 shows that exports account for $34.9 \%$ of these effects. Thus, these exports led alone to a $12.7 \%$ growth $(46.0 \% \times 79.5 \% \times 34.9 \%)$ of the agricultural sector between 2000 and 2009.

Table 7 - Decomposition of the effects of final demand, by its components (\%)

\begin{tabular}{|c|c|c|c|}
\hline \multirow[b]{2}{*}{ Sector } & \multicolumn{3}{|c|}{ Demand component } \\
\hline & Exports & $\begin{array}{c}\text { Government consumption } \\
\text { expenditure }\end{array}$ & NPISH consumption \\
\hline Agriculture & 34.9 & 3.5 & 0.3 \\
\hline Industry & 18.1 & 7.5 & 0.6 \\
\hline \multirow[t]{2}{*}{ Services } & 9.1 & 25.5 & 1.7 \\
\hline & \multicolumn{3}{|c|}{ Demand component } \\
\hline Sector & $\begin{array}{c}\text { Personal consumption } \\
\text { expenditure }\end{array}$ & $\begin{array}{l}\text { Gross fixed capital } \\
\text { formation }\end{array}$ & Changes in inventories \\
\hline Agriculture & 50.9 & 23.1 & -12.7 \\
\hline Industry & 51.1 & 36.9 & -14.2 \\
\hline Services & 57.0 & 8.7 & -2.0 \\
\hline
\end{tabular}

Source: Data compiled by the author based on the Input-Output Matrices for 2000 and the System of National Accounts data for 2009, both published by IBGE.

According to Table 7, both for agriculture and for industry, the most relevant final demand components were exports, personal consumption expenditure and gross fixed capital formation. Conversely, the most relevant components for the service sector appear to have been government and personal consumption. It may therefore be concluded that, on the one hand, exports and gross fixed capital formation had significant impacts on the agricultural and industrial sectors, but only secondary effects on services. On the other hand, the opposite was observed for government consumption: a relevant effect on services, but a secondary one on the other sectors.

Finally, Table 8 shows similar results to those of the previous table, but disaggregated into the 12 activities that make up the sectors. As to the industrial sector, this decomposition allows a clearer distinction between the effects of each component of final demand: the mineral extraction industry was fostered mainly by exports; the manufacturing industry, by personal consumption and by gross fixed capital formation; generation and distribution of electricity, by personal consumption; and, finally, the construction industry, by gross fixed capital formation.

In its turn, the service sector was influenced mainly by personal consumption. Government consumption, which was relevant for services at the aggregate level, at the disaggregated level seems to basically influence public administration, health and education services (however, it is worth mentioning a secondary but relevant effect of this component on the services of information and of financial intermediation, insurance, and pension funds). 


\section{Table 8 - Disaggregated decomposition of the effects of final demand, by its components (\%)}

\begin{tabular}{|c|c|c|c|}
\hline \multirow[b]{2}{*}{ Activity } & \multicolumn{3}{|c|}{ Demand component } \\
\hline & Exports & $\begin{array}{l}\text { Government } \\
\text { consumption } \\
\text { expenditure }\end{array}$ & $\begin{array}{c}\text { NPISH } \\
\text { consumption }\end{array}$ \\
\hline Agriculture & 34.9 & 3.5 & 0.3 \\
\hline Mineral extraction industry & 78.0 & 2.5 & 0.2 \\
\hline Manufacturing industry & 12.1 & 7.6 & 0.7 \\
\hline Generation and distribution of electricity, gas and water & 17.7 & 11.7 & 0.8 \\
\hline Construction & 0.3 & 8.6 & 0.2 \\
\hline Trade & 15.2 & 4.1 & 0.6 \\
\hline Transport, storage and mail services & 23.1 & 6.5 & 0.7 \\
\hline Information services & 7.7 & 15.0 & 1.1 \\
\hline Financial intermediation, insurance and pension funds & 7.0 & 15.9 & 0.3 \\
\hline Real estate activities and rent & 3.8 & 2.0 & 0.2 \\
\hline Other services & 12.5 & 6.1 & 5.3 \\
\hline \multirow[t]{2}{*}{ Public administration, health and education } & 0.3 & 99.1 & 0.0 \\
\hline & \multicolumn{3}{|c|}{ Demand component } \\
\hline Activity & $\begin{array}{c}\text { Personal } \\
\text { consumption } \\
\text { expenditure }\end{array}$ & $\begin{array}{c}\text { Gross } \\
\text { fixed capital } \\
\text { formation }\end{array}$ & $\begin{array}{l}\text { Changes in } \\
\text { inventories }\end{array}$ \\
\hline Agriculture & 50.9 & 23.1 & -12.7 \\
\hline Mineral extraction industry & 18.2 & 12.0 & -10.9 \\
\hline Manufacturing industry & 59.2 & 37.8 & -17.3 \\
\hline Generation and distribution of electricity, gas and water & 61.5 & 14.2 & -5.9 \\
\hline Construction & 12.9 & 78.5 & -0.5 \\
\hline Trade & 61.0 & 22.6 & -3.6 \\
\hline Transport, storage and mail services & 59.4 & 16.3 & -5.9 \\
\hline Information services & 73.0 & 5.3 & -2.0 \\
\hline Financial intermediation, insurance andpension funds & 72.6 & 7.1 & -2.9 \\
\hline Real estate activities and rent & 83.0 & 11.6 & -0.5 \\
\hline Other services & 71.7 & 6.1 & -1.6 \\
\hline Public administration, health and education & 0.5 & 0.3 & -0.2 \\
\hline
\end{tabular}

Source: Data compiled by the author based on the Input-Output Matrices for 2000 and the System of National Accounts data for 2009, both published by IBGE.

\section{CONCLUSIONS}

As previously highlighted, the manufacturing's declining share of GDP observed in the Brazilian economy since the 1970s has fostered a strong debate about its causes and consequences. This paper sought to contribute to this debate by revealing, among other results, that the major determinant of the growth differential between services and industry in the 2000s was the lower intermediate consumption of domestic industrial inputs by the production chain of all economic sectors. 
In addition, this paper shows that if, on the one hand, the increase in final demand played an important role in the growth of the Brazilian economy in the 2000s, on the other the magnitude and direction of the influence of each component of this demand were quite heterogeneous. In fact, the results allowed drawing the following conclusions:

(i) Personal consumption was relevant for the whole economy.

(ii) Gross fixed capital formation was important to both the manufacturing and construction industries.

(iii) Exports were relevant mainly to the mineral extraction and agricultural industries.

(iv) Government consumption had a significant impact only on public administration, health and education services, in addition to a secondary but important effect on information and financial intermediate on services. In the remainder of the economy, it played a less important role.

It was not within the scope of the present study to assess whether the concern with the smaller share of industry in the GDP is valid, or whether compensatory measures for the industry are desirable. However, it is possible to conclude that, if policy makers are interested in such compensatory measures and if one wants to offset the changes in the production structure with stimulus for the aggregate demand, one should create incentives for gross fixed capital formation, to the detriment of government consumption. This conclusion is supported by Dasgupta and Singh (2006) and Rowthorn and Ramaswamy (1999), who find positive correlations between the level of gross fixed capital formation and the share of manufacturing in employment and production.

However, Dos Santos and Pires (2009) show that private investment in Brazil is little sensitive to changes intaxes, implying that the ability of policymakers to induce an increase in the former variable through the traditional tools of fiscal policyis very limited. In this sense, Demir (2009) employs a model of portfolio choice in order to explain the low investment rates of three developing countries (Argentina, Mexico and Turkey) during the 1990s. The author argues that, given risk, uncertainty, imperfections in capital markets and relative returns, firms may prefer to make reversible short-term financial investments than irreversible long-term fixed ones. This can also be the reason lying behind the insensitivity of Brazilian private investment in relation totaxes, but that remains a hypothesis to be investigated in future research.

\section{REFERENCES}

BAUMOL, W. J. Macroeconomics of unbalanced growth: the anatomy of urban crisis. American Economic Review, v. 57, n. 3, p. 415-426, 1967. 
BONNELLI, R.; PESSÔA, S. A. Desindustrialização no Brasil: um resumo da evidência. Texto para Discussão, IBRE, Fundação Getúlio Vargas, n. 7, 2010.

DASGUPTA, S.; SINGH A. Manufacturing, services and premature deindustrialization in developing countries - a Kaldorian analysis. UNU-WIDER Research Paper, n. 2006/49, 2006.

DEMIR, F. Financial liberalization, private investment and portfolio choice: financialization of real sectors in emerging markets. Journal of Development Economics, v. 88, n. 2, p. 314-324, 2009.

DOS SANTOS, C. H.; PIRES, M. C. C. Qual a sensibilidade dos investimentos privados a aumentos na carga tributária brasileira? Uma investigação econométrica. Revista de Economia Política, v. 29, n. 3, p. 213-231, 2009.

FELDMAN, S. J.; MCCLAIN, D.; PALMER, K. Sources of structural change in the United States, 1963-78: An input-output perspective. The Review of Economics and Statistics, v. 69, n. 3, p. 503-510, 1987.

GUILHOTO, J.; SESSO FILHO, U. Estimação da matriz insumo-produto utilizando dados preliminares das contas nacionais: aplicação e análise de indicadores econômicos para o Brasil em 2005. Revista Economia e Tecnologia, v. 6, n. 4, p. 53-62, 2010.

KONGSAMUT, P.; REBELO, S.; XIE, D. Beyond balanced growth. Review of Economic Studies, v. 68 , n. 4 , p. $869-882,2001$.

KUZNETS, S. Modern economic growth: rate, structure and spread. New Haven and London: Yale University Press, 1966

LIM, H.; YOO, S.; KWAK, S. Industrial $\mathrm{CO}_{2}$ emissions from energy use in Korea: A structural decomposition analysis. Energy Policy, v. 37, n. 2, p. 686-698, 2009.

MA, C.; STERN, D. I. China’s changing energy intensity trend: A decomposition analysis. Energy Economics, v. 30, n. 3, p. 1.037-1.053, 2008.

MACIENTE, A. N. The determinants of agglomeration in Brazil: input-output, labor and knowledge externalities. Doctoral dissertation, Agricultural and Consumer Economics, Graduate College, University of Illinois, Urbana-Champaign, 2013.

NASSIF, A. Há evidências de desindustrialização no Brasil? Revista de Economia Política, v. 28, n. 1, p. 72-96, 2008.

NGAI, L. R.; PISSARIDES, C. A. Structural change in a multisector model of growth. American Economic Review, v. 97, n. 1, p. 429-443, 2007.

OREIRO, J. L.; FEIJÓ, C. A. Desindustrialização: conceituação, causas, efeitos e o caso brasileiro. Revista de Economia Política, v. 30, n.2, p. 219-232, 2010.

ROSE, A.; CASLER, S. Input-output structural decomposition analysis: a critical appraisal. Economic Systems Research, v. 8, n. 1, p. 33-62, 1996.

ROWTHORN, R.; RAMASWAMY, R. Growth, trade, and deindustrialization. IMF Staff Papers, v. 46, n. 1, p. 18-41, 1999.

SKOLKA, J. Input-output structural decomposition analysis for Austria. Journal of Policy Modeling, v. 11, n. 1, p. 45-66, 1989. 